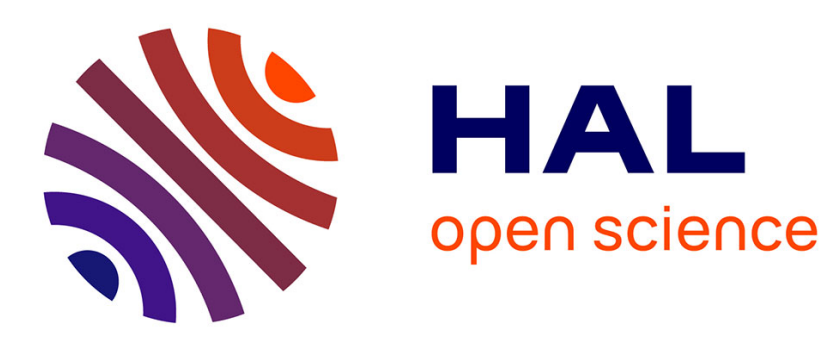

\title{
Ensuring the effective implementation of transnational company agreements
}

\author{
André Sobczak
}

\section{To cite this version:}

André Sobczak. Ensuring the effective implementation of transnational company agreements. European Journal of Industrial Relations, 2012, 18 (2), pp.139-151. 10.1177/0959680112440762 . hal00956968

\section{HAL Id: hal-00956968 \\ https://hal.science/hal-00956968}

Submitted on 7 Apr 2015

HAL is a multi-disciplinary open access archive for the deposit and dissemination of scientific research documents, whether they are published or not. The documents may come from teaching and research institutions in France or abroad, or from public or private research centers.
L'archive ouverte pluridisciplinaire HAL, est destinée au dépôt et à la diffusion de documents scientifiques de niveau recherche, publiés ou non, émanant des établissements d'enseignement et de recherche français ou étrangers, des laboratoires publics ou privés. 


\title{
Ensuring the effective implementation of transnational company agreements
}

\section{André Sobczak}

Audencia Nantes School of Management, France

\section{Corresponding author:}

André Sobczak, Audencia Nantes -- École de Management, 8 route de la Jonelière B.P. 31222, 44312 Nantes Cedex 3, France.

Email: asobczak@audencia.com

\begin{abstract}
Over the past decade, a number of European companies have negotiated transnational company agreements. These agreements may help improve labour standards in the subsidiaries, and even more for those employed by subcontractors or suppliers. They may also encourage social dialogue at these levels. However, given their uncertain legal status, how it is possible to ensure their effective implementation throughout the company's subsidiaries? What matters is less the legal status of the transnational collective agreement than the active involvement of the various actors involved in the process. The role of the signatories to the agreement is of course crucial, but its effective implementation also requires the commitment of local managements and workers' representatives. This article draws on discussions and interviews with managers and worker representatives directly involved in the implementation of transnational company agreements, and identifies ways to encourage this kind of commitment.
\end{abstract}




\section{Keywords}

transnational collective agreements, transnational social dialogue, European social dialogue, European Works Councils

\section{Introduction}

During the last two decades, transnational social dialogue within the EU has developed at crossindustry (Clauwaert, 2011; de Boer et al., 2005), sectoral (Léonard, 2008; Perrin and Léonard, 2011) and company levels (Schoemann et al., 2008; Telljohann et al., 2009). This development is linked to increasing internationalization of business and the consequent need for social regulation at international level (Papadakis, 2008). Even though links increasingly exist between the various levels of transnational social dialogue (Léonard and Sobczak, 2010), we are still far from the sort of systematic, formalized structure linking the three levels which exists in some national contexts. In particular, whereas Articles 154 and 155 of the EU Treaty define precise rules for the negotiation and implementation of transnational agreements at cross-industry and sectoral levels, there is currently no specific legal framework for transnational company agreements (Ales et al., 2006; Sobczak, 2007). However, the lack of a specific legal framework has not hindered the development of transnational company agreements; indeed some argue that certain employers would not have signed such agreements if these had a clear legally binding character.

Whereas transnational social dialogue at the cross-industry and sectoral levels remains almost exclusively limited to the EU, almost half of the existing transnational company agreements have a worldwide scope of application, covering workers in all subsidiaries (European Commission, 2008). The majority of the companies that have signed these agreements have their head office in one of the EU member states, mainly Germany or France, even if the last five years have seen an increasing development of transnational company agreements in countries outside the EU. The content of agreements of worldwide scope is quite different from those applying only within Europe, usually covering various aspects of corporate social responsibility (Hammer, 2005). First, they refer, almost as 
a matter of course, to the fundamental social rights defined by the International Labour Organisation (freedom of association, equal opportunities and prohibition of forced and child labour). Second, they often cover working conditions issues that are also discussed at national level, such as health and safety, training, responsible restructuring or respect for national and international minimum standards regarding remuneration and working time. Third, they often also include broader issues concerning relations with other stakeholder groups, such as environmental protection, involvement in local communities or the fight against AIDS. Agreements with a purely European scope usually focus on one specific subject (European Commission, 2008). Most such texts are related to restructuring, either setting out social guarantees for a specific plant or defining general principles for the future, such as rights on information and consultation of workers' representatives or lifelong training (Moreau, 2009; Scarponi and Nadalet, 2010). Other European agreements concern equal opportunities or diversity management. Finally, some texts at this level cover technical matters such as data protection or financial participation.

The negotiations involve a variety of actors. Those with a worldwide scope always involve one or more Global Union Federations (GUFs). However, almost half of these texts are co-signed by the national union(s) of the country where the company has its head office, and a quarter by the company's European Works Council (EWC). Two-thirds of the agreements with a European scope of application are signed by the EWC, and the rest are negotiated by European Trade Union Federations (ETUFs) or GUFs. National unions are only very rarely signatories of agreements with a purely European scope, indicating that the European organizations have achieved sufficient legitimacy to replace national ones. This does not yet seem to be the case at international level.

None of these mechanisms helps to clarify the legal status of the negotiated agreements (Daugareilh, 2005; Drouin, 2005; Sobczak, 2007). GUFs and ETUFs are organized at sectoral level and can negotiate agreements at this level with employers' organizations, if these exist. However, there is no legal authority for them to negotiate agreements with specific companies. EWCs, by contrast, represent employees at company level, but the directive establishing them does not give them any right to negotiate collective agreements. Finally, national unions that represent the employees at 
the company's head office have no legitimacy to negotiate agreements that apply to the workers in subsidiaries in other countries.

Given this uncertain legal status, how it is possible to ensure the effective implementation of transnational company agreements throughout a company's subsidiaries in order to strengthen workers' rights (Fichter et al., 2011; Scarponi, 2011)? Effective implementation probably depends less on the legal status of the transnational collective agreement than on the power and active involvement of all relevant actors in the process. The role of the signatories is of course crucial, but its effective implementation also requires the commitment of local managements and workers' representatives.

This article draws on discussions and interviews with managers and worker representatives directly involved in the implementation of transnational company agreements, and identifies several means to create or strengthen such commitment. I develop my argument in three sections. First, I discuss the impact of legal status on the effective implementation of transnational company agreements, in an attempt to go beyond the traditional distinction drawn between hard and soft law. Second, I analyze various procedures which may be developed at corporate level to ensure effective implementation, highlighting the fact that current solutions are often insufficient. Third, I explore means of enhancing the active involvement of local stakeholders, both managers and worker representatives. In conclusion, I discuss possible future research in this area.

\section{Distinguishing between legal status and effective implementation}

The lack of a precise legal status for transnational company agreements does not mean that these texts have no legal effects (Lo Faro, this issue). Nor does it mean that they have no impact on working conditions or the quality of social dialogue within the company (Mund and Priegnitz, 2007). In several national industrial relations systems, collective agreements are not legally binding and are considered 'gentlemen's agreements', yet this does not mean that employers do not respect them (Rehbahn, 2003; 2004). Clearly, then, the legally binding nature of a collective agreement is neither a sufficient, nor a necessary condition for its effective implementation. 
There are many examples of legally binding labour standards which are not effectively implemented in the companies to which they in theory apply, as is particularly evident in the area of equal opportunities and anti-discrimination. Over recent decades, many legally binding texts have been adopted at EU and national level to strengthen the rights of workers and job applicants in this area (Jacobs, 2005); but unequal treatment still occurs. Similarly, despite EU and national legislation requiring that workers' representatives be informed and consulted before decisions are taken that may lead to the loss of jobs, this principle is not effectively respected, since consultation usually occurs only after the decision is already taken. To a certain extent, the development of transnational company agreements is itself evidence that the legally binding character of a labour standard is insufficient to guarantee its effective implementation. Indeed, many of the provisions in these agreements, in particular those with a worldwide scope, refer to respect for ILO conventions or even national labour laws that are already legally binding. They may, of course, extend these rights to new categories of workers, in particular employees in subsidiaries with lower labour standards and those working for suppliers and subcontractors who are often less protected in law and in fact (Sobczak, 2003). Their main added value, however, is not in the creation of new rights, but in the commitment of all the signatories to contribute proactively to the effective implementation of existing standards. GUFs and ETUFs therefore pay increasing attention to the definition of precise measures for the implementation and monitoring of transnational company agreements. In other words, by concluding such agreements, companies and their union counterparts aim to complement the public authorities, in particular those carrying out labour inspections, in monitoring compliance with labour standards. This may raise questions about the legitimacy of these private actors, but it also offers new opportunities, as long as the new private monitoring procedures do not replace the public ones.

On the other hand, as Trubek and Trubek (2005) put it, 'soft law may be harder than you think'. Soft law is defined by a lack of legal enforceability, which is not the same as effectiveness (Lascoumes and Serverin, 1986). Several examples show that practices which are in no way legally binding may be effectively implemented, if the parties involved understand and accept the aims and either feel pressure from external stakeholders or have an interest in creating a long-term interorganizational learning process (Berthoin Antal and Sobczak, 2004). Civil society and consumers are, 
indeed, increasingly interested in the social practices of companies. They expect them to respect their commitments in this area and even to resist social dumping by refusing to exploit national jurisdictions offering a lower level of worker protection. Companies which do not respect their 'voluntary commitments' in the area of corporate social responsibility may be subject to boycotts or even legal proceedings, charged with misleading advertising (Sobczak, 2006). Even in the area of social dialogue, there are several European countries where collective agreements are respected not because they are legally enforceable, but because of the need of the social partners to create mutual trust in order to establish long-lasting relationships.

Consequently, the difference between hard and soft law should not be overstated. They are not totally different in nature; rather, there are variations in effectiveness within both categories. In theory, legally binding labour standards are more likely to be implemented effectively than non-binding ones; but this presupposes that the public authorities have the will and capacity to monitor the application of the relevant legislation and to sanction any breach. This is not always the case (Hepple, 2002). In many countries, legally binding standards are observed only if the local actors are aware of the legislation, consider it relevant and legitimate and have the power to enforce it, either through lawsuits or through such means as organizing collective action or alerting the media and other stakeholders, including those in other countries. These are the same measures that may be used to press managers to respect non-binding texts.

In order to ensure the effective implementation of a labour standard, it is therefore less important to achieve legally binding provisions than to set up appropriate internal monitoring processes and to provide local stakeholders with knowledge and understanding of the standard. The GUFs and ETUFs seem to recognize this. For example, the International Metalworkers' Federation (IMF) considers that the enforcement of transnational company agreements depends almost entirely on union strength. It therefore recommends and encourages its affiliates to report any breaches of such agreements by local managers. It considers that workers' representatives should plan how to implement the agreement before signing, and should develop education and training to ensure that affiliates are equipped to ensure genuine implementation. Similarly, the Building and Wood Workers' International (BWI) sees the success of any global company agreement as depending on the strength 
of unions at national level: proper implementation is only possible if workers are organized in free trade unions and are able to bargain collectively at the national and enterprise levels. Along the same lines, the International Federation of Chemical, Energy, Mine and General Workers' Unions (ICEM) considers that monitoring mechanisms are a key ingredient of transnational company agreements, since they make them into practical, living documents. This better enables monitoring of a company's performance and means that agreements can be amended or improved in the light of experience.

Consequently, the GUFs do not consider the adoption of a legal framework for transnational company agreements a priority. Rather, they try to integrate more detailed provisions on implementation and monitoring into the agreements which they negotiate (Schoemann et al., 2008; Telljohann et al., 2009). This strategy is compatible with the strong opposition of employers' associations towards any kind of legal framework, even on an optional basis, for transnational collective bargaining, and the resulting difficulties facing the European Commission in moving forward in this field (Dufresne, this issue). In this context, in order to guarantee the impact of transnational company agreements, it may be more efficient to concentrate efforts on involving all relevant actors in the implementation process, both at head offices and in subsidiaries, rather than fighting for a legal framework that is unlikely to be adopted.

\section{Coordinating implementation at head office}

Most transnational company agreements, in particular the most recent ones, contain precise provisions as to how the signatories at the head office should monitor implementation within the different subsidiaries. Unlike unilateral corporate social responsibility initiatives such as codes of conduct, which are increasingly monitored through external audits (Schoemann et al., 2008), such processes are usually internal and based on social dialogue, since they involve workers' representatives at different levels in the company. This choice has advantages for both management and trade unions. Managers at the headquarters establish an internal warning system which can give them information on social problems in the subsidiaries, which may be hidden from them by local management, and can allow 
them to implement corrective actions before the situation reaches the media, social rating agencies and the general public (Sobczak, 2011). The procedures developed to monitor transnational company agreements may thus be seen as a way of managing reputational risks (Sobczak, 2008). For trade unions, developing such internal control mechanisms not only improves compliance with labour standards throughout the subsidiaries, but also helps to strengthen local unions and to promote transnational cooperation. This in itself is one of the reasons for negotiating such agreements (Müller et al., 2008).

To coordinate implementation at the company's head office, almost all transnational company agreements provide for at least an annual meeting between the signatories to discuss the initiatives taken, the challenges met and the results obtained. For example, the 2005 agreement on corporate social responsibility and international industrial relations between the French building materials company Lafarge and the BWI, ICEM and World Federation of Building and Woodworkers' Unions (WFBW) established 'a reference group consisting of representatives of the Lafarge management and the signatory international federations [to] meet at least once a year, or whenever necessary, to follow up and review the implementation of this agreement'.

Some transnational agreements open up these meetings to workers' representatives other than those who have signed the text. This is, for example, the case of texts with worldwide scope which have not been signed by the EWC: the ETUF or GUF may have refused to allow it to sign the agreement since its members are not necessarily trade unionists, but may still admit its legitimacy in the monitoring process (Dufresne, this issue). Thus the 2008 international framework agreement between Italcementi and BWI to promote and protect workers' rights provided for 'a reference group... composed of representatives of Italcementi and the concerned BWI affiliated union(s) in the home country of the company, the EWC Coordinator and a BWI Coordinator. It will meet at least once a year, or when necessary, to evaluate reports on compliance and to review the implementation of the agreement.'

Some agreements contain very detailed provisions concerning the annual meeting, such as the documents to be sent to the workers' representatives beforehand, the time to be spent on discussions and the budget to be provided by the company for translations and travelling (Sobczak, 2011). The 
2009 agreement on corporate social responsibility between the French electricity company EDF and ICEM, Public Services International (PSI), International Federation of Mining and Energy (IFME) and several national unions, provided for the creation of a 'Consultation Committee on EDF Group Corporate Social Responsibility' (CCSR) to meet annually, adding that 'in the event of a request from the majority of the members, and with the agreement of the Chairman, a special session may be held'. 'A preparatory meeting and a follow-up meeting' is to take place on each occasion. Participants 'shall be given time in the company that employs them to prepare and participate in the annual CCSR meeting': 4 days a year for ordinary members, with extra allowances for members of the CCSR Bureau, and a special provision for the Secretary. In addition, EDF 'covers the costs directly related to the functioning of the follow-up on the CSR Agreement (CCSR meetings, Bureau, interpretation and translations). The transportation costs are covered by the companies of the Group'. Management is to arrange language training in French or in English, where necessary.

The requirement to hold these regular meetings is an interesting initiative that does not exist for many hard law standards. The legislator tends to consider that the legally binding character of the latter is sufficient to guarantee effective implementation without any further systematic monitoring procedures. The non-legally binding character of transnational company agreements, in contrast, encourages their signatories, in particular the workers' representatives, to develop specific processes to ensure that the provisions have a tangible effect on the working conditions and the quality of social dialogue in the various subsidiaries. Furthermore, these regular meetings contribute to the recognition of the transnational group as a new and legitimate level of social dialogue (Müller, 2009; Schoemann et al., 2008).

Analysis of the implementation processes within different transnational company agreements shows, however, that organizing annual meetings is not enough. To promote effective implementation it may be necessary to prepare detailed reports on actions carried out in the different subsidiaries to conform to the principles defined in the text, and to develop performance indicators. The global agreement on fundamental rights, social dialogue and sustainable development between GDF SUEZ, BWI, ICEM and PSI in 2010 stated that 'each company covered by this agreement will propose its methods of application within the framework of joint action plans. The application is intensely 
monitored with the trade union partners based on accessible and objective indicators. Where trade union partners cannot be involved, other methods will be examined and jointly agreed.'

Defining such performance indicators, which must be consistent with other indicators used by the company in the area of corporate social responsibility and more generally, might risk creating a shift from a bilateral to a unilateral approach. Management is unlikely to agree to discuss these performance indicators with workers' representatives, since they are a key tool for the management of human resources. Given the often rather broad scope of transnational company agreements, in particular those which apply globally, it is also important to provide worker representatives at the headquarters with information or even training on the issues covered by the agreement. This is true, for example, if the agreement covers matters such as environmental protection or the fight against AIDS, which are not the standard subjects dealt with by workers' representatives and may thus require additional expertise. Such an approach may help to stimulate an organizational learning process aimed at improving working conditions and social dialogue in all parts of the company through cooperation with workers' representatives (Berthoin Antal and Sobczak, 2004). In some cases, the existence of a transnational company agreement allows headquarters representatives to organize visits to subsidiaries in different parts of the world, to give them a better knowledge of local priorities and expectations. Although such visits may be difficult to organize and costly, they are more likely to produce the expected effect on working conditions and social dialogue, but also in terms of risk management, than just the signature of the agreement and minimal involvement in its monitoring by means of an annual meeting that is not sufficiently prepared.

As well as developing such a proactive monitoring procedure, the signatories to transnational company agreements may define complaint mechanisms to allow workers in the subsidiaries to report violations of the principles set out in the text. Some transnational agreements contain such provisions. The 2005 framework agreement between the aeronautics company EADS and its EWC specified that 'trade union or works council representatives may inform central management orally or in writing of any breach' of one or more terms of the agreement. In such cases, 'EADS central management shall take appropriate measures to eliminate any breach of the aforesaid principles, reporting on any measures taken to a plenary session of the EWC' and 'the EWC may submit proposals for corrective measures 
to ensure compliance with this agreement to the management of EADS or the relevant Business Unit.' Finally, the agreement states that 'in a situation of conflict, the arbitration process will be mutually agreed by the EADS head of Human Resources and the EWC.'

Usually, the workers or their local representatives must initially discuss the problem with local management. If the problem cannot be resolved at this level, the worker or the local union may contact the national union, which will discuss the issue with the national company headquarters. If the problem can still not be resolved, it becomes the responsibility of the signatories of the transnational agreement to deal with the conflict. This approach, respecting the principle of subsidiarity, has the advantage of involving managers and workers' representatives at all levels, while giving priority to conflict resolution at local level. It would be dangerous to give workers in the subsidiaries the impression that head office could be brought in to challenge any decision by local managers; and local actors would not be encouraged to take initiatives to adapt the transnational agreement to local circumstances, if all decisions were to be taken by the head office. Hence while the signatories at head office are responsible for coordinating implementation of the transnational company agreement, the main actors are those in the subsidiaries, since they need to find ways to achieve the aims defined in the text while taking account of the local culture and context.

\section{Involving local stakeholders in implementation}

Involving local managers and workers' representatives in the implementation of transnational company agreements is both one of the most difficult and one of the most important challenges for the signatories at headquarters level. Agreeing on the common values and principles that should govern working conditions and social dialogue in all parts of the company should not be too complicated a task for managers and workers' representatives at central level. Many transnational company agreements have similar contents (da Costa et al., this issue), which shows that once the two parties have decided to open negotiations, they have a fairly clear idea of the outcome. In most cases, 
negotiations take only a few months, and both parties rarely mention major difficulties in the process (Schoemann et al., 2008). What seems much more difficult is to convince local stakeholders of the benefits of a transnational agreement, which may contain principles that are not in line with local legislation, traditions and practices. Whereas local workers' representatives may see the transnational agreement as an opportunity to improve working conditions and to strengthen their position in social dialogue, local managers often perceive the principles it contains as constraints that are not always in line with their own management culture. This is particularly true for the provisions relating to social dialogue, since the added value of workers' rights on information and consultation is far from accepted in all parts of the world, and may provoke open hostility in Asia, and also in North America.

To help local managers and worker representatives understand the aims of the transnational agreement and to reflect on the way it may enrich their own practices, it seems important to involve them at an early stage of the process. Unfortunately, such an approach is far from widespread among existing agreements. For the employer, managers at head office conduct the transnational negotiations and at best consult informally certain local managers as to the process or particular critical issues; it is very unusual for local managers to be included in the negotiating team. This may be explained by a desire to facilitate and accelerate negotiations, as well as by the difficulties involved in selecting the right local managers, yet the experience of those companies which have involved local managers in the negotiation process shows that this procedure favours faster and more effective implementation. First, local managers feel a closer connection with the agreement if they have been involved at an early stage rather than learning about it once it has been signed. Second, their involvement may make it possible to avoid potential tensions with local legislation or cultures.

The same reasoning applies to the involvement of local workers' representatives. It may be tempting to negotiate transnational company agreements with transnational representative bodies such as GUFs, ETUFs or EWCs. This may avoid long discussions as to the representativeness of the various local actors, and accelerate the negotiation process. The risk is, however, that local representatives then learn of the transnational agreement without understanding the intentions of the signatories, nor how it can be adapted to their local context. The transnational agreement is thus likely to remain a virtual prospect without real impact on the working conditions and on local social dialogue 
(Marginson and Sisson, 1998). Conversely, by involving local representatives at an early stage, the signatories at head office level can encourage effective implementation of their transnational agreement.

Such involvement, however, remains the exception. Only half of those transnational agreements with a worldwide scope of application, and very few of those with a European scope, have been co-signed by national unions. Furthermore, in almost all cases, the only national unions involved in the negotiation process are those of the country of the head office. EDF seems to be the only company that has involved national unions from all countries in which it has subsidiaries (Sobczak, 2011), a choice that was ambitious but possible, given the moderate number of its subsidiaries. The French car-producer Renault negotiated its transnational agreement with the IMF, but informed the various national unions of the process and invited them to co-sign the agreement to give it additional legitimacy. This option seems easier to replicate than the EDF model. It is close to the internal procedure set out by the European Metalworkers' Federation (EMF), which has decided not to open any negotiation on a transnational company agreement before consulting the various national unions and getting a mandate to negotiate (Dufresne, this issue). Moreover, EMF will not sign the final agreement until the national unions have approved the result.

Once a transnational company agreement has been signed, the signatories at head office level must encourage local management and workers' representatives to implement effectively the principles defined in the text. According to the 'basic principles of social responsibility' agreed between Bosch, its EWC and the IMF in 2004, the aim of the signatory parties is to implement these principles throughout the whole group. These principles will be incorporated into the 'Management System Manual for Quality, Environment, Safety, and Security in the Bosch Group'. The agreement states that the 'responsibility for their implementation lies with the senior management of the respective divisions, regional subsidiaries and company locations.'

Some transnational agreements refer explicitly to implementation through decentralized social dialogue, which is an excellent way to involve the local actors. For example, the Global Framework Agreement on Social Responsibility between PSA Peugeot Citroën and the IMF, EMF and several 
national unions in 2006 provided that 'in each of the major countries local social observatories will be set up. These will be made up of human resources divisions and labour unions. The social observatories will monitor the application of the Global Framework Agreement on an annual basis using a common monitoring document to be created jointly by the parties to this agreement.'

There is of course a risk of reintroducing national differences, but the aim of the transnational agreement is usually less to harmonize working conditions throughout the company than to set up minimum standards that may always be improved at subsidiary level. In other words, the idea is to create a multi-level system of social regulation combining transnational and national norms rather than setting the two against each other (Marginson and Sisson, 2004; Sciarra, 2010).

It is important to ask local management to report on the specific progress made with reference to the provisions of the agreement. Some companies organize annual meetings with the top management of all subsidiaries to prepare for the meeting of head office signatories. In a few cases, performance indicators are developed to measure the results obtained. For local management, this underlines the importance attached by head office to the effective implementation of the agreement. It also allows headquarters managers to communicate more effectively on the actions developed at local level, the results obtained and the remaining challenges. Some companies have used this knowledge to create databases of innovative practices to inspire those in other subsidiaries.

It may also be desirable to train local workers' representatives, to help them develop the right initiatives to achieve the aims set out in the transnational agreement. Some companies, for example, organize training on issues frequently included in these agreements but which do not necessarily correspond to the traditional activities of local workers' representatives, such as the integration of disabled workers or the in-depth analysis of the company's accounts in order to make appropriate proposals in the case of restructuring. Such training programmes, which can be jointly organized by management and workers' representatives, seem necessary for the effective implementation of these agreements, in particular if they cover issues which are new to the local workers' representatives.

To promote effective implementation of transnational company agreements, therefore, the signatories at head office level must thus develop innovative processes aimed at involving local 
management and workers' representatives and encouraging them to integrate provisions of the agreement into their strategies and activities. In other words, the signing of a transnational company agreement does not mark the end of the negotiation process, but rather the starting point of an organizational learning process throughout the subsidiaries. What counts is less the formal content of the agreement than the procedures put in place to encourage and maintain this learning process. It does not seem necessary to include all details concerning the implementation process in the text of the agreement. Such an approach may even risk discouraging decentralized initiatives by local players if they have not been included in the transnational agreement. The transnational agreement should rather be seen as offering a framework for organizational learning at all levels of the company rather than as a text designed to harmonize working conditions and social dialogue throughout the company.

\section{Conclusions}

This article is based on interviews with managers and workers' representatives who have been involved in the negotiation of transnational agreements. These interviews have been mainly limited to companies with their headquarters in France, where most such agreements have been negotiated. Future research should cover a broader range of companies, in order to analyze whether those in other countries have developed similar procedures to implement these agreements effectively, and whether they have had the same positive experience. Interviews should of course also be conducted in at least some of the subsidiaries, to find out how local managers and workers' representatives perceive these agreements and their involvement in implementation. It would also be interesting to broaden this research to the impact on working conditions and social dialogue for suppliers and subcontractors, since many transnational company agreements contain provisions that cover these. Such an ambitious research project would require global networks of researchers, in order to organize interviews in different countries with the local actors. It also presupposes support from the head office signatories, to convince local actors to take part in such research. For all these reasons, the launching of this type of research project is a difficult task. Nevertheless, it seems to be a necessary next step in order to 
continue to learn more about the effective implementation of transnational company agreements and thus guarantee their future development.

\section{References}

Ales E., Engblom S., Jaspers T., Laulom S., Sciarra S., Sobczak A. and Valdes Dal-Ré F. (2006). Transnational Collective Bargaining: Past, Present and Future. Final Report. Brussels: European Commission, DG Employment, Social Affairs and Equal Opportunities.

Berthoin Antal A. and Sobczak A. (2004). 'Beyond CSR: Organisational Learning for Global Responsibility', Journal of General Management 30(2): 77-98.

Clauwaert S. (2011). '2011: 20 years of European interprofessional social dialogue: achievements and prospects', Transfer 17(2): 169-79.

de Boer R., Benedictus H. and van der Meer M. (2005). 'Broadening without Intensification: The Added Value of the European Social and Sectoral Dialogue', European Journal of Industrial Relations 11(1): 51-70.

Daugareilh I. (2005). 'La négociation collective internationale', Travail et Emploi 104: 69-84.

Drouin C.-R. (2005). International Framework Agreements: A Study in Transnational Labour Regulation. $\mathrm{PhD}$ thesis, University of Cambridge.

European Commission (2008). Mapping of transnational texts negotiated at corporate level. Brussels: European Commission, DG Employment, Social Affairs and Equal Opportunities.

Fichter M., Helfen M. and Schiederig K. (2011). 'Kann transnationale Solidarität auf Konzernebene organisiert werden? Der Ansatz der internationalen Rahmenabkommen'. In F. Gerlach, T. Greven and U. Mückenberger (eds.), Solidarität über Grenzen: Gewerkschaften vor neuer Standortkonkurrenz. Berlin: edition sigma, 75-92.

Hammer N. (2005). 'International Framework Agreements: global industrial relations between rights and bargaining', Transfer 11(4): 511-30. 
Hepple B. (2002). 'Enforcement: the law and politics of cooperation and compliance'. In B. Hepple (ed.). Social and Labour Rights in a Global Context, Cambridge: Cambridge University Press, $238-57$.

Jacobs F. G., ed. (2005). EU Anti-discrimination law, Oxford University Press, Oxford.

Lascoumes P. and Serverin E. (1986). ‘Théories et pratiques de l'effectivité du droit', Droit \& Société 2:127-50.

Léonard E. (2008). 'European Sectoral Social Dialogue: An Analytical Framework', European Journal of Industrial Relations 14(4): 401-19.

Léonard E. and Sobczak A. (2010). 'Accords transnationaux d'entreprises et dialogue social sectoriel européen : quelles interactions ?', Travail et Emploi 121: 43-54.

Marginson P. and Sisson K. (1998). 'European Collective Bargaining: A Virtual Prospect?', Journal of Common Market Studies 36(4): 505-28.

Marginson P. and Sisson K. (2004). European Integration and Industrial Relations: Multi-Level Governance in the Making. Basingstoke: Palgrave Macmillan.

Moreau M. A. (ed.) (2009). Building Anticipation of Restructuring in Europe. Brussels: Peter Lang.

Müller T., Platzer H.-W. and Rüb S. (2008). Internationale Rahmenvereinbarungen. Chancen und Grenzen eines neuen Instruments globaler Gewerkschaftspolitik. Bonn: Friedrich-EbertStiftung, Kurzberichte Globale Gewerkschaftspolitik 8.

Müller M. (2009). 'Internationale Rahmenabkommen: Neue Räume für den gewerkschaftlichen Internationalismus?'. In E. Ehmke, M. Fichter, N. Simon and B. Zeuner (eds.). Internationale Arbeitsstandards in einer globalisierten Welt, Wiesbaden: VS Verlag, 224-42.

Mund H. and Priegnitz K. (2007). 'Soft law: second best solution or a privatisation for social rights? Some pointers for a future discussion', Transfer 13(4): 671-77.

Papadakis K. (ed.) (2008). Cross-border social dialogue and agreements: An emerging global industrial relations framework? Geneva: International Institute for Labour Studies.

Perrin E. and Léonard E. (2011). 'European sectoral social dialogue and national social partners', Transfer: European Review of Labour and Research, Vol. 17, No. 2, 159-168. 
Rebhahn R. (2003). 'Collective labour law in Europe in a comparative perspective (Part 1): Collective agreements, settlement of disputes and workers' participation', International Journal of Comparative Labour Law and Industrial Relations 19(3): 271-95.

Rebhahn R. (2004). 'Collective labour law in Europe in a comparative perspective (Part 2)', International Journal of Comparative Labour Law and Industrial Relations 20(1): 107-32.

Scarponi S. (2011). 'Gli accordi transnazionali a livello di impresa: uno strumento per contrastare il social dumping', Lavoro e diritto 25(1): 119-40.

Scarponi S. and Nadalet S. (2010). 'Gli accordi transnazionali sulle ristruturazioni d'imprese', Lavoro e diritto 24(2): 211-34.

Schoemann I., Sobczak A., Voss E. and Wilke P. (2008). Codes of conduct and international framework agreements: New forms of governance at company level. Report to the European Foundation for the Improvement of Living and Working Conditions, Dublin.

Sciarra S. (2010). Collective Exit Strategies: New Ideas in Transnational Labour Law. New York: NYU School of Law, Jean Monnet Paper 04/10.

Sobczak A. (2003). 'Codes of Conduct in Subcontracting Networks: A Labour Law Perspective', Journal of Business Ethics 44(2-3): 225-34.

Sobczak, A. (2006). 'Are Codes of Conduct in Global Supply Chains Really Voluntary? From Soft Law Regulation of Labour Relations to Consumer Law', Business Ethics Quarterly 16(2): $167-84$

Sobczak A. (2007). 'Legal Dimensions of International Framework Agreements in the Field of Corporate Social Responsibility', Relations Industrielles/Industrial Relations 62:3): 466-91.

Sobczak A. (2008). 'Syndicats et responsabilité sociale des multinationales', Gestion: Revue internationale de Gestion 33(1): 18-26.

Sobczak A. (2011). La responsabilité globale, moteur du dialogue social. Nantes: Audencia, Cahier de la Responsabilité Globale 5.

Telljohann V., da Costa I., Müller T., Rehfeldt U. and Zimmer R. (2009). 'European and international framework agreements: new tools of transnational industrial relations', Transfer 15(3-4): 50525 . 
Trubek D. M. and Trubek L. G. (2005). 'Hard and Soft Law in the Construction of Social Europe: the Role of the Open Method of Co-ordination', European Law Journal 11(3): 343-64.

\section{Author biography}

André Sobczak is Associate Professor and Research Director in Management at Audencia Nantes School of Management. 